\title{
The Long March in Hong Kong: Continuing Steps in the Transition from Colony to Democracy
}

Thomas S. Axworthy

Herman B. Leonard

Follow this and additional works at: http://open.mitchellhamline.edu/wmlr

\section{Recommended Citation}

Axworthy, Thomas S. and Leonard, Herman B. (2007) "The Long March in Hong Kong: Continuing Steps in the Transition from Colony to Democracy," William Mitchell Law Review: Vol. 33: Iss. 2, Article 10.

Available at: http://open.mitchellhamline.edu/wmlr/vol33/iss2/10 


\title{
THE LONG MARCH IN HONG KONG: CONTINUING STEPS IN THE TRANSITION FROM COLONY TO DEMOCRACY
}

\author{
Thomas S. Axworthy ${ }^{\dagger}$ and Herman B. Leonard ${ }^{\dagger \dagger}$
}

I. ThE STRUCTURE OF GOVERNANCE IN HONG KONG ............... 535

II. PRINCIPLES OF GOVERNANCE AND ACCOUNTABILITY ............ 543

III. INTERNATIONAL COMPARISONS.......................................... 551

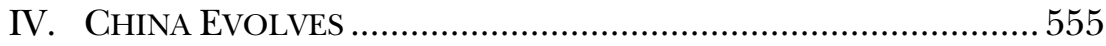

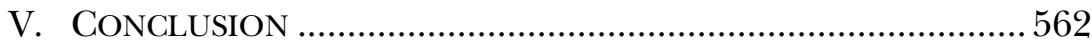

Avowedly apolitical, Hong Kong is in the midst of the most rapid political transition in China, and the success of this transition is crucial not only for the seven million residents of Hong Kong, but also for the future of China itself. How the authorities in Beijing respond to democratic demands from Hong Kong, and how the government of Hong Kong treads a democratic pathway within the boundaries of the Basic Law, are two of the most important questions in international politics today. China's decisions about Hong Kong will tell us much about the prospects of democratic transformation in China itself, and on that crucible the future of the twenty-first century might turn.

Hong Kong was once an island of political stability punctuated by occasional bursts of tumult, as in the 1967 riots. ${ }^{1}$ Today Hong

+ Queen's University.

t† Harvard University.

1. The view of Hong Kong as a politically indifferent economic city has long prevailed. The best-known advocate of this position is Siu-kai Lau, who has written extensively on the subject. See generally Sui-Kai Lau, From Traditional Familism to UTILITARIANISM FAMILISM (1978). In a 1995 article, Lau and Hjin-chi Kuan described the people of Hong Kong as "the attentive spectators." Sui-kai Lau \& Hjin-chi Kuan, The Attentive Spectators: Political Participation of the Hong Kong Chinese, 14 J. Ne. Asian STUd. 3 (1995). This view is robustly contested by Lam Wai-man. See generally Lam Wai-man, Understanding the Political Culture of Hong Kong: The PARAdox OF ACTIVISM AND Depoliticization (2004). 
Kong is in perpetual political motion punctuated by short timeouts to catch its political breath. Becoming a British colony after the 1840 Opium War, Hong Kong grew slowly as a port and commercial entrepot, ruled by a British governor. ${ }^{2}$ The economic transformation of Hong Kong into a world-class city was given a mighty push after the Second World War as the Chinese Communist Party (CCP) won the civil war against Chiang Kai-shek. ${ }^{3}$ Hong Kong became a refuge from the communists as entrepreneurial talent, capital, and large numbers of people flowed into the island from south China after 1949. ${ }^{4}$ To its everlasting credit, Britain encouraged a strong civil society and built an impressive liberal state. An impartial, honest, and competent civil service, the rule of law, autonomous unions, churches, the press, and an economic strategy of minimal interference in the capitalist economy are all part of Hong Kong's impressive inheritance from Westminster. In particular, with the creation of the Independent Commission Against Corruption in the 1970s, Hong Kong became a leader in creating a professional nonpartisan civil service. ${ }^{5}$ Hong Kong became an island of freedom, civility, and stability in a very tough neighborhood. A substrate consisting of the rights and institutions that underlie democracy-freedoms of speech, of association, of religion, of assembly; a vibrant free press; a tolerance of political criticism and debate about government and other issues-was gradually laid down, and over time grew deeply ingrained. Hong Kong thus developed what we might call a strong "culture of liberty" - which by itself does not constitute or provide democracy, but which is a necessary foundation for any democratic institutions worthy of the name. What Britain did not attempt-at least until 1992, when it sent Chris Patten, the first governor from a political background (and, some would say, even thereafter) - was any serious development of locally based institutions of direct

2. See JAn Morris, Hong Kong 136-37 (1985) (describing Hong Kong as the "most important entrepot of the China coast"); see also G.B. ENDACOTT \& A. Hinton, Fragrant Harbour: A Short History of Hong Kong 20 (2d ed. 1968) (noting that Hong Kong was officially declared a British colony in June of 1843). See generally Frank Welsh, A Borrowed Place: The History of Hong Kong 280313 (1993); Jack BeEching, The ChInESE OpIUM WARs (1975).

3. See Steve Shipp, Hong Kong, China: A Political History of the British Crown Colony's Transfer to Chinese Rule 12-16 (1995). See Endacott \& Hinton, supra note 2, at 34-35; The Hong Kong Reader: Passage to Chinese Sovereignty 56-57 (Ming K. Chan \& Gerald A. Postiglione eds., 1996).

4. See SHIPP, supra note 3, at 14.

5. See WELSH, supra note 2, at 492-93, 531. 
democracy. The British Foreign Office and the local economic elite were content to portray Hong Kong as an economic oasis, uninterested in politics, so that when Mrs. Thatcher's government negotiated the return of Hong Kong to China, one sovereign power simply replaced another. The people of Hong Kong had no say in the matter. The Basic Law was crafted in the mid-1980s, but it was not applied until 1997. ${ }^{6}$ The British continued the executiveled government that had ruled the colony, and the Chinese were happy to accept this model. Patten himself made a valiant effort to create a more democratic culture and a new set of institutions (over the opposition of the Foreign Office), but it was too little and too late to have much impact on the basic structure of the system in place at the time of the handover. ${ }^{7}$ Britain bequeathed liberty, but it did not bequeath democracy.

\section{THE STRUCTURE OF GOVERNANCE IN HONG KONG}

Starting in 1997, then, Hong Kong has had to develop its political institutions on the fly. There has been almost constant political change since the handover, and the pace of democratization, though gradual, has been steady. When Britain began to negotiate with China over the Basic Law in the 1980s, for example, 100 percent of the legislators were appointed by the British governor. ${ }^{8}$ Since the September 2004 election, none of the legislators are appointed. ${ }^{9}$ The main institutional elements can be

6. See Jonathan Dimbleby, The Last Governor: Chris Patten and the HANDOVER OF HONG KONG 51 (1997).

7. Christopher Patten describes his experience as the last governor of Hong Kong (and his frustration with the lack of British government support in disputes with China prior to the 1997 handover) in EAST AND WEST: CHINA, POWER, AND THE FUTURE OF ASIA (1998). Britain only began introducing democratic reforms after it had initiated discussions with Beijing over the handover. Thus, talks began in 1979, and elections for District Council were not introduced until 1982. Dimbleby, supra note 6 , at 104-06. In 1984, the governments of Britain and China reached an agreement to return Hong Kong to Chinese sovereignty in 1997, but the people of Hong Kong had no say in the matter. Id. at 50-52. There was no vote, only a consultation with those who were affected most. Id. In 1985, an indirect election component of functional constituencies was added to the Legislative Council, only after the 1984 Joint Declaration. Joseph Chan \& Elaine Chan, Perceptions of Universal Suffrage and Functional Representation in Hong Kong: A Confused Public?, 46 AsIan SuRvey 257, 259 (2006). In 1991, for the first time there were direct elections for eighteen of the sixty LegCo seats. Id. Patten's travails are described in DimblebY, supra note 6.

8. Chan \& Chan, supra note 7, at 258.

9. Id. at 259 . 
succinctly sketched: the Basic Law makes clear that Hong Kong is a part of China, albeit with a fifty-year window until 2047 in which the city will enjoy special status as a Special Administrative Region (HK SAR), keeping both liberty and a capitalist economy. ${ }^{10}$ The Basic Law outlines the rights and duties of the Chief Executive, the legislature, and the judiciary. ${ }^{11}$ There is unlikely to be any mistake about the ultimate arbiter of Hong Kong's fate-in March 2004, for example, the Standing Committee of China's National People's Congress interpreted the Basic Law's provisions to circumscribe Hong Kong's current debate on democratic reform. ${ }^{12}$ Reform toward universal suffrage in selecting the Chief Executive in 2007 or the legislature in 2008 would proceed only if a "need" was demonstrated and then in a "gradual and orderly manner." the schedule and substance of democratic reform will require support of two-thirds of the Legislative Council (LegCo), consent of the Chief Executive and the approval of the Standing Committee. $^{14}$ Beijing made it clear in April 2004 that any reforms in 2007 or 2008 will be incremental and within the existing spirit of the Basic Law. ${ }^{15}$

The Chief Executive is selected by an Election Committee of eight hundred, ${ }^{16}$ which itself is determined by a complicated formula involving 180,000 voters. ${ }^{17}$ Limited to two five-year terms, in 1996 shipping magnate Tung Che Hwa won an easy victory (320 votes) over Ti Lang Yang (forty-two votes) and Peter Woo (thirty-six

10. XiangGang Ji Ben fa, Art. 5 [hereinafter Basic LAW].

11. BASIC LAW, Chap. IV.

12. See Decision of the Standing Committee of the National People's Congress on Issues Relating to the Methods for Selecting the Chief Executive of the Hong Kong Special Administrative Region in the Year 2007 and for Forming the Legislative Council of the Hong Kong Special Administrative Region in the Year 2008, S.S. No. 5 to Gazette Extraordinary No. 8/2004, at E7, available at http: //www.info.gov.hk/basic_law/fulltext/0426npcsc_e.pdf [hereinafter Decision of the Standing Committee].

13. Id. at E9, E11.

14. BASIC LAW, Art. 159.

15. Decision of the Standing Committee, supra note 12, at E5, E7.

16. Basic LaW, Art. 45; Annex I.

17. See Press Release, Bureau of Democracy, Human Rights and Labor, U.S. Dep't of State, Country Reports on Human Rights Practices-2001 (Mar. 4, 2002), available at http://www.state.gov/g/drl/rls/hrrpt/2001/eap/8289.htm. For the December 10, 2006 election, the election committee pool of voters increased in to over 200,000, of this pool over 50,000 voted to elect a committee of 800 . See Press Release, Electoral Affairs Commission, Subsector Elections Concluded with 427 Members Returned to Election Committee (Dec. 11, 2006), available at http:// www.hketony.gov.hk/usa/press/2006/dec06/121106.htm. 
votes). ${ }^{18}$ In 2002, Tung was reelected unopposed. ${ }^{19}$ Further, in 2002, Tung initiated a major change in the executive system of Hong Kong. Prior to 2002, the functions of policymaking and administrative communication had been based in the Hong Kong public service, with the policy secretaries of the departments and bureaus the key executive actors. ${ }^{20}$ The Executive Council, a holdover from its days as the main advisory body to the Colonial Governor, was composed of civil servants, LegCo members, and representatives of the "great and good" of Hong Kong, i.e., academics, business people, and community activists. ${ }^{21}$ In 2002, Tung proposed, and the legislature agreed, to change this system by appointing fourteen principal officials as the political heads of the departments and bureaus or de facto ministers, serving at the pleasure of the Chief Executive. ${ }^{22}$ Called the "Accountability System for Principal Officials," the accountability of the officials is to the Chief Executive, not to the legislature or people of Hong Kong. ${ }^{23}$ Under Tung, the twenty-one-member Executive Council had fourteen principal officials or ministers joined by seven other nominees drawn from the Legislature and the wider community. ${ }^{24}$ In Canada, such members of the Cabinet without departmental authority are called "Ministers Without Portfolio." Representatives of parties in the Legislature sit on the Executive Council, but have not yet served as principal officials or political heads of the departments or bureaus, and there is debate whether Article 79(4) of the Basic Law prohibits this evolution. ${ }^{25}$ In October 2005, in his

18. See generally Phillip Bowring, Hong Kong: The Unknown Future Boss Won't Be 'Elected', InT'L HerALd TrIB., Oct. 30, 1996, available at http://iht.com/articles/ 1996/10/30/edbow.t_1.php.

19. See Hong Kong Government Homepage, 2002 Chief Executive Election, Election Result http://www.elections.gov.hk/elections/ce_election/result_e.htm (last visited Jan. 22, 2007) (stating that Tung was the only validly nominated candidate).

20. See generally WELSH, supra note 2 , at $486-88$.

21. See id. at 486.

22. See Letter from Joseph W. P. Wong, Sec'y for the Civil Serv., Gov't of the Hong Kong Special Admin. Region, to Colleagues (Apr. 17, 2002), available at http://www.csb.gov.hk/print/english/letter/943.html (outlining the proposal's "main points").

23. Id.

24. See Press Release, Hong Kong Econ. \& Trade Office, San Francisco, Chief Executive Appoints Officers to Serve in New Accountability System (June 24, 2002), available at http://www.hketosf.gov.hk/sf/ehk/ehongkong12/chiefexec utive.htm.

25. See generally BASIC LAW, Art. 79(4). 
first Policy Address as Chief Executive, Donald Tsang announced further changes to the Executive Council and Principal Officials' accountability system: only Tsang and the top three Principal Officials (Chief Secretary, Finance, and Justice) will attend all meetings of the Executive Council. ${ }^{26}$ Other officials will attend only when there are items on the agenda affecting their portfolios. ${ }^{27}$ Tsang also appointed eight new non-official members to the Council, making a total of twenty-nine. ${ }^{28}$

Tung's second five-year term as Chief Executive came to an early close in March of 2005 when he resigned, citing health reasons. $^{29}$ The official line was challenged by, among others, Christine Loh, the feisty head of the Civic Exchange think tank, who mused in her newsletter that Tung's early demise was rooted in Beijing's concern that the incumbent had lost credibility and could no longer maintain stability within Hong Kong. ${ }^{30}$ The Chief Secretary Donald Tsang became Acting Chief Executive according to the process outlined in Article 53 of the Basic Law. ${ }^{31}$ The Standing Committee of the National People's Congress ruled that the new Chief Executive will serve for approximately two years (until 2007), being the end of Tung's prior term, as set forth in the electoral timetable contained within the Basic Law. ${ }^{32}$ In May of

26. See Press Release, Hong Kong Gov't, Framework of Accountability System for Principal Officials (Apr. 17, 2002), available at http://www.info.gov.hk/gia/ general/200204/17/0417251.htm.

27. Id.

28. See Press Release, Hong Kong Econ. \& Trade Office, Hong Kong Chief Executive Appoints New Members to Executive Council (Oct. 14, 2005), available at http://www.hketousa.gov.hk/usa/press/oct05/ny_101405.htm [hereinafter Chief Executive Appoints New Members].

29. Press Release, Constitutional Affairs Bureau, Acting Chief Executive's Opening Statement (Mar. 12, 2005), available at http://www.cab.gov.hk/cd/eng/ media/p031205.htm.

30. In her newsletter, Tung's Rumours, Loh suggests that Premier Wen Jiabao himself "dressed down" Tung in December 2004, and that the senior leadership in January 2005 decided that Tung had to go. Christine Loh, Tung's Rumours, CIVIC EXCHANGE, Mar. 6, 2005, http:/ / www.civic-exchange.org/?p=236.

31. Any concerns regarding the relative credibility (and ensuing social stability) of the former Chief Executive would appear to be well founded. A Hong Kong University Poll taken in May of 2005 indicated that Donald Tsang enjoys a "confidence level" of 77 percent. AFX News Limited, Hong Kong's Caretaker Leader Tsang Enjoys Broad Public Support (May 10, 2005), http://www.forbes. com/finance/feeds/afx/2005/05/10/afx2016669.html. At the time Tung left office, he held an approval rating of 18 percent and a "no-confidence" rating of 69 percent. Id.

32. Standing Committee of the Tenth National People's Congress, The Interpretation by the Standing Committee of the National People's Congress of 
2005, Mr. Tsang resigned as Acting Chief Executive to run in the election; ${ }^{33}$ he was nominated in June by nearly seven hundred of the eight hundred members of the Election Committee. ${ }^{34}$ Since his two opponents failed to receive the one hundred votes necessary to run in the election, Tsang was elected unopposed. He was appointed Chief Executive on June 21, 2005 by the Council of State of China. ${ }^{35}$ The next election for Chief Executive will be March 25, $2007 .^{36}$

LegCo has sixty members, thirty directly elected by a proportional representation system based on universal suffrage, and thirty elected from functional constituencies of business groups, accountants, and so on-a limited franchise (similar to the franchise that selects the Election Committee that chooses the Chief Executive). ${ }^{37}$ The Legislature passes laws proposed by the Chief Executive and its approval is required to authorize the budget. $^{38}$ LegCo has the right to debate policy and question the principal officials, but it has no role in the Executive, and private member bills require concurrent majorities among both the geographic members elected on universal suffrage, and of the functional constituencies. $^{39}$ In the September 2004 election, democratic reform advocates won 62 percent of the vote and twenty-five seats in the sixty-seat legislature. ${ }^{40}$ Turnout was a healthy 55.6 percent. ${ }^{41}$ Democratic advocates are proposing that a

Article 7 of Annex I and Article III of Annex II to the Basic Law of the Hong Kong Special Administrative Region of the People's Republic of China, L.S. No. 2 to Gazette Ext. No. 5/2004, at B431, available at http://www.info.gov.hk/basic_law/ fulltext/0406npcsc_e.pdf.

33. See Hong Kong Government Website, Donald Tsang Resigns (May 25, 2005), http://www.news.gov.hk/en/category/administration/050525/html/0505 25en01002.htm.

34. See Xinhua, Donald Tsang Appointed Chief Executive of HKSAR (2005), http://english.sina.com/taiwan_hk/p/1/2005/0621/35475.html [hereinafter Xinhua,Tsang Appointed].

35. See Hong Kong Government Website, Donald Tsang Appointed Chief Executive (June 21, 2005), http://www.news.gov.hk/en/category/administration/ 050621/html/050621 en01002.htm.

36. See Xinhua, Tsang Appointed, supra note 34 (noting that Donald Tsang's term will expire by June 30, 2007).

37. BASIC LAW, Annex II.

38. Id. at Art. 73.

39. Id. Annex II.

40. See Hong Kong Government Website, 2004 Legislative Council Election (Sept. 13, 2004), http://www.elections.gov.hk/elections/legco2004/english/ results/rs_fc_overall.html [hereinafter 2004 Election Results].

41. See Press Release, Hong Kong Gov't Info. Ctr., HKSAR Government 
referendum be held on whether the functional seats' limited voting system should be replaced by universal suffrage, ${ }^{42}$ but this initiative has been opposed both by the Chief Executive and Beijing. In January 2004, former Chief Executive Tung created a Task Force on the Constitution, headed by then-Chief Secretary Donald Tsang, to suggest institutional reforms. ${ }^{43}$ Changes there may be, but universal suffrage in 2007 for the Chief Executive and 2008 for the legislature will not be among them. In the fall of 2005, Tsang proposed a modest expansion of the Election Committee to 1,600 members from eight hundred and increase of LegCo by ten members. ${ }^{44}$ But Tsang's package failed to gain the necessary twothirds of the members of LegCo with near unanimity of opposition from the democratic bloc.

The pace of democratic reform remains a source of great concern for many reformers. The institutional strength of the LegCo and the structure of its electoral system-which is thought to create obstacles for opposition movements-have also been flagged as problematic by those in the pro-democratic camp. ${ }^{46}$ The legitimacy of existing elections, however, would not likewise appear to be in dispute. In the wake of complaints regarding the integrity of the September 2004 LegCo elections, the Chief Executive commissioned an investigative report to look at the management, planning, conduct, and monitoring of elections. ${ }^{47}$ The findings of

Responds to US Congressional-Executive Commission on China's Hearing on HK (Sept. 24, 2004), available at http://www.info.gov.hk/gia/general/200409/24/ 0924290.htm (noting that 55.6 percent, representing a 1.7 million voter turnout, was a historic high).

42. Janus Lam, Hong Kong Democracy Fire Stoked Again, Asia Times Online, Nov. 17, 2004, http://www.atimes.com/atimes/China/FK17Ad03.html.

43. See Press Release, Hong Kong Gov't Info. Ctr., Chief Secretary's Speech on Constitutional Development Task Force's Visit to Beijing (Feb. 11, 2004), available at http://www.info.gov.hk/gia/general/200402/11/0211260.htm (speaking on a number of principles outlining the future development of Hong Kong).

44. See Press Release, Hong Kong Gov't Info. Ctr., CE's Speech at the Wilton Park Conference (Nov. 4, 2005), available at http://www.info.gov.hk/gia/general/ 200511/04/P200511040005.htm. Tsang outlined his proposal as "a significant step forward on the road to universal suffrage." $I d$.

45. See Associated Press, China Criticizes Hong Kong Lawmakers for Rejecting Planned Political Change, INT'L HERALD TRIB., Dec. 22, 2005, available at http://iht.com/articles/2005/12/22/news/hong.php (calling the vote a setback for both Beijing and Donald Tsang).

46. Joseph Y. S. Cheng, Hong Kong's Democrats Stumble, 16 J. Democracy 141 (2005).

47. Hong Kong Government Website, Report of the Independent Committee 
the "Independent Committee of Experts" would suggest that, despite some procedural kinks and potential for improvement, the elections were fair and independent. ${ }^{48}$ International observers likewise confirmed that the September elections were seen as generally free, open, and contested. ${ }^{49}$

A final point of reference is the engagement and expectations of the citizens of Hong Kong. Voters may not have the right to cast their ballot for the Chief Executive, but they do have the liberty to demonstrate, and this right they have exercised exuberantly. In 1989, one million turned out to protest the Tiananmen Square outrage. $^{50}$ On July 1, 2003, a massive demonstration of 500,000 citizens opposed the government's proposed legislation on internal security. ${ }^{51}$ The legislation was withdrawn and the principal official responsible for the legislation resigned. On July 1, 2004, another huge demonstration of approximately 200,000 people demanded advancement of democracy in Hong Kong. ${ }^{52}$ Prior to the December 2005 LegCo vote on Tsang's Constitutional package, another 80,000-200,000 marched peacefully for universal suffrage. $^{53}$ With 3.2 million voters, demonstrations of such magnitude comprise 10-15 percent of the voting base, while parties in North America and Europe are happy to have 1-2 percent of their membership turn out for a major event. Public criticism by LegCo members, supplemented by a hypercritical media, has already forced the resignations of three principal officials in the short time since the accountability system was introduced. Moderation is still the center of political gravity in Hong Kong: democrats won most of the votes in September 2004, but the proBeijing Democratic Alliance for the Betterment of Hong Kong

of Experts for the Review on the Management, Planning and Conduct of Elections (May 6, 2005), http://www.info.gov.hk/info/report05/index.htm.

48. Id

49. Bureau of East Asian and Pacific Affairs, U.S. Department of State, Background Note: Hong Kong (Sept. 2006), http://www.state.gov/r/pa/ei/ bgn/2747.htm.

50. See SHIPP, supra note 3, at 70.

51. Philip P. Pan, Huge Crowd Marches Again for the Vote in Hong Kong, WASH. Post Foreign Serv., July 2, 2004, at A08.

52. Mark L. Clifford et al., Behind the Revolt: The Rise of People Power Has Changed Hong Kong and China Forever, Bus. WK. OnLINE, July 21, 2003, http:/ /www. businessweek.com/magazine/content/03_29/b3842007_mz046.htm.

53. Kent Ewing, Hong Kong Democracy Movement Gets New Life, Asia Times OnLINE, Dec. 6, 2005, http://www.atimes.com/atimes/China/GL06Ad02.html. 
(DAB) party won the most seats (twelve). ${ }^{54}$ Yet far from its reputation for political apathy, Hong Kong is in fact in a democratic boil. Expectations are high and the public is aroused. All parties support democratization. Both Beijing and the new Chief Executive will have to handle the Constitutional file with great finesse. Tsang's first effort at reform resulted in a narrow legislative defeat-but the issue will not go away.

The continuing importance of the debate over democracy is illustrated by four recent events: first, by the formation, in March of 2006, of a new Civic Party, committed to democracy; ${ }^{55}$ and second, by the emergence of Anson Chan as a proponent of more rapid progress toward universal suffrage-and, possibly, as a contestant in the next election for Chief Executive. Chan, former Chief Secretary and a major figure in Hong Kong's governmental landscape (as viewed both from Hong Kong and internationally), held a press conference on June 26, 2006 to lend her prestige to the democratic wing, saying, "Mr. Tsang should show more effort and courage to fight for democracy. ${ }^{, 56}$ She also announced that she would be marching in upcoming pro-democracy demonstrations, and refused to rule out a future campaign for Mr. Tsang's job. ${ }^{57}$ A third event that has brought attention to universal suffrage is the return of Regina Ip, the former secretary of security, to Hong Kong from a sabbatical in the United States. Ip, who championed the draconian Article 23 that brought half a million into the streets, surprised many by advocating in her Master's thesis both achieving universal suffrage in 2012 and amending the Basic Law to allow "the organic nexus between the executive and legislative branches." 58

54. See 2004 Election Results, supra note 40; Robin Fitzsimons, The Joint Declaration: Who Will Stick Up for Hong Kong's Right to Decide, InT'L Herald TriB., Sept. 16, 2004, available at http://www.iht.com/articles/2004/09/16/edrobin_ed3 _.php (stating that a record number of voters opted for democracy); Philip Bowring, Hong Kong Elections: When Winners Lose, the Message Is the Victory, INT'L Herald TriB., Sept. 10, 2004, available at http://www.iht.com/articles/2004/09/ 10/edbowring_ed3_.php (calling the election an important symbolic role).

55. See generally Civic Party Website, News About CP, http://www.civicparty. hk/cp/pages/cpnews-e.php (last visited Feb. 19, 2007).

56. Press Release, Anson Chan Speech (June 26, 2006) (on file with authors).

57. Id.

58. Regina Ip Lau Suk Yee, Hong Kong: Case Study in Democratic Development in Transitional Society (2006) (unpublished M.A. thesis, Stanford University) (on file with authors, summary available at http://savantas.org/ docs/HKDemocraticDevelopment-e.pdf). 
The most dramatic democratic advance occurred in January 2007, when Alan Leung, a well-known lawyer and member of LegCo, was nominated by the Civic party to contest the election for Chief Executive in March 2007. Leung announced that he obtained enough nominations (one hundred) from the eighthundred member Election Committee to be a formal candidate in the March 25, 2007 election. In December 2006, democratic leaders, like Anson Chan, had urged voters who were entitled to vote in the election for members of the Election Committee to support a democratic slate. More than 50,000-out of the eligible voting pool of over 200,000 - participated in the election. ${ }^{59}$ A prodemocracy coalition backed a slate of 137 candidates, and they succeeded in electing sufficient numbers to sign Leung's nomination papers. The incumbent, Donald Tsang, is the overwhelming favorite since more than half of the Election Committee of eight-hundred is appointed by Beijing and their allies. But the Tsang-Leung contest means that Hong Kong will have its first opportunity to select its Chief Executive in a contested election. Interestingly, the March 2007 election will also be the first election in recent years where a territory controlled by the Communist Party of China will have the semblance of a real contest.

\section{PRINCIPLES OF GOVERNANCE AND ACCOUNTABILITY}

As a background to our examination of the governance and accountability system in place in Hong Kong, it is useful first to establish some general principles as a point of departure. All societies face the challenge of organizing and legitimating collective activities-identifying public interests, setting priorities for public action, designing ways in which the prioritized interests can be advanced, collecting the necessary resources, and carrying out the decided programs. ${ }^{60}$ The challenge of governing can be divided into two broad areas: 1) legitimate political decision making that recognizes and sets priorities among competing public interests; and 2) competent, efficient, and effective design and administration of the legitimately chosen public actions. A good

59. See Press Release, Electoral Affairs Commission, supra note 17.

60. See generally Adam Przeworski et al., Sustainable Democracy 35 (1995) (discussing the need for both citizens and states to define their roles and obligations to each other). 
governance system must thus provide effectiveness both for political decision-making and for competent execution. In addition, it needs to provide some sort of evidence (to whom) about its performance on the public's behalf-and what sanctions can be applied to it (and by whom) if its performance is found wanting.

Accountability systems answer the question: "Who is responsible to whom for what?" It is about responsibility, the responsibility of those using delegated authority to answer for their actions. Government accountability frameworks concentrate on two main questions: What is the system by which the government is accountable to the citizenry? What is the system by which the public service is accountable to the political leadership? The new accountability system of Hong Kong tries to address the question of how the public service can be made accountable to the Chief Executive, but it is silent on the prior question of how the government as a whole is to be made accountable to the citizens of Hong Kong.

In full democratic electoral accountability systems, citizens through their vote legitimize and formally give authority to leaders to act on their behalf. In their turn, those who have been delegated the power to make decisions-prime ministers, presidents, permanent secretaries, directors-general, etc.-must answer for how they have discharged the duties that they have been delegated. As Adam Przeworski emphasizes in Sustainable Democracy:

The conditions under which democratic institutions generate incentives for government to be accountable are quite stringent; they are not met by all institutional frameworks. Governments are accountable only when voters can clearly assign the responsibility for performance to competing teams of politicians, when the incumbents can be effectively punished for inadequate performance in office, and when voters are sufficiently well informed to accurately assess this performance. ${ }^{61}$

Therefore, there are three A's in any democratically viable system: authority, accountability, and answerability.

Authority is the formal power to act. But how does it happen that one person has authority over others? This is one of the perennial questions in political philosophy. As humankind

61. PRZEWORSKI, supra note 60 , at 108. 
progressed from the family to the tribe, to the city, to the state, force was the initial source of authority. We obeyed because others were stronger. But those who held power because of the sharpness of their swords soon discovered that force was not enough. Willingness to obey was better if freely given, so divine right was brought into play. Authority was found in God and interpreted by his delegates on earth. Emperors and kings were happy to promote their divinity. Yet, starting in Athens in the fifth century and slowly gaining momentum through the ages until it was proclaimed as a new principle of authority in Britain's Glorious Revolution of 1688, and America's Revolution in 1776, was the idea that human beings are free agents, bound only by conscience, so that political authority exists only because we consent to obey it. What is critical is not force, but the psychological disposition that it is right to obey. According to Pierre Trudeau, in an essay written prior to becoming Prime Minister of Canada, "Human Societies, then, differ from the beehives in that men are always free to decide what form of authority they will adopt, and who will exercise it. And it really is men who have the responsibility of taking these decisionsnot God, Providence, or Nature."

Willing obedience-as contrasted with begrudging compliance-then, depends upon the perception that authority has legitimacy. There are many different ways for governments to earn legitimacy. Competence and effectiveness in understanding and advancing the public's interests can confer legitimacy to a degree-for example, the Allied administration of post-war Germany came to be regarded by most as a legitimate system of governance, even though it was initially imposed by force, because it manifestly was designed to be (and was in practice) competently serving the interests of those it governed. ${ }^{63}$ But in the twenty-first century, for most people, more complete legitimacy will have to be earned by facing an electoral test-a process of one person and one vote. $^{64}$ Elites that rely on force or a rigged electoral process will eventually face a legitimacy crisis because sooner or later their

62. Pierre Elliott Trudeau, Approaches to Politics 31 (I. M. Owen trans., 1970).

63. See Formula for Germany, Time, Oct. 2, 1944, available at http://www.time. com/time/magazine/article/0,9171,933104,00.html (describing the tripartitioninto three separate administrative zones-of Germany during post World War II occupancy).

64. See PrZEWORSKI, supra note 60 , at 108. 
citizens will choose not to obey. ${ }^{65}$ However, this has not yet occurred in either China or Hong Kong.

In recent decades, a unique mix of China's socialist ideology together with a general desire for social stability and economic development has contributed to the people's "choice" to obey their political leadership. But the ideology of the Chinese Communist Party has been substantially reoriented in light of expansive market reforms, and the capacity of the PRC to ensure social stability will continue to be called the test of the regime.

Yet democratic electoral legitimacy is obviously the biggest challenge for the Hong Kong accountability framework, because neither the governance structure of the Hong Kong Special Administrative Region nor that of the People's Republic of China relies on direct election with universal suffrage. The Chief Executive is selected by a committee of eight hundred, not the 3.2 million voters of Hong Kong, and the Basic Law is interpreted by a political body of the National People's Congress (not a court), which itself is the product of a one-party system that does not face a broad electoral test. The Basic Law itself acknowledges the authority-legitimacy dilemma in Hong Kong, since Article 68 proclaims that "[t]he ultimate aim is the election of all the members of the Legislative Council by universal suffrage." ${ }^{67}$ The Basic Law states the aim but not the timetable and is hedged with restrictions.

The impact of this structure is profound: the intent of the Basic Law is to have an executive-led system. ${ }^{68}$ The passage of a government bill requires a simple majority of the legislative body while bills on amendments introduced by LegCo members require majorities both from the democratically elected members and the functional constituencies. ${ }^{69}$ LegCo cannot introduce measures pertaining to public expenditure (although its approval is required

65. Id.

66. Data and opinion based on the legitimacy of the CCP can be found, for example, in Mary E. Gallagher, Reform and Openness: Why China's Economic Reforms Have Delayed Democracy, 54 World Politics 338 (2002). See also Jie Chen, Popular Political SupPORT In URBAn China 179-84 (2004). In his book, Chen concludes that, although the PRC enjoys a high level of legitimacy in Beijing, diffuse and specific support for the regime is on the decline, and, if current trends persist, could pose a threat to CCP rule in the long run. Id. at 183-84.

67. BASIC LAW, Art. 68.

68. Id. Art. 43, 60 (stating that the Chief Executive shall be the head of the HK SAR).

69. Id. Annex II, § 2. 
for the Executive Committee's budget),${ }^{70}$ and the Chief Executive has the power to decide whether government officials must give evidence to LegCo. ${ }^{71}$ But the exercise of those strong theoretical powers has made plain the real weakness of the HK SAR's executive-led government, because in any conflict with the legislature, it is the LegCo members who have democratic legitimacy, not the Chief Executive. After the July 1, 2003 massive demonstration, the Chief Executive had to withdraw his legislation on internal security because the Liberal party head, James Tien, resigned from the Executive Committee in protest and with the loss of the Liberal party's eight votes, the legislation would have been voted down. $^{72}$ LegCo routinely attacks the principal officials, who often resign because the government does not have enough democratic legitimacy to withstand negative bursts of public opinion. Despite having party representatives from the Legislature as members of the Executive Council, the government cannot count on a guaranteed base of party support. Stephen Lam, the Secretary for Constitutional Affairs joked in a July 30, 2004 speech to the Hong Kong Democratic Foundation that " $[t]$ he Hong Kong government is the most effective minority government on earth. We do not have even one Member in the Legislative Council, but we manage to get most of our work done." ${ }^{, 73}$ Echoing Lam, Mrs. Rita Fan, the President of the Legislative Council, said in an October 26, 2004 speech to the same audience that "[t]he Government had the power but no votes, while the Legislature had the votes but no power." this legitimacy-authority gap must be closed.

70. Id. Art. 74 (requiring Legislative Council members to obtain the written consent of the Chief Executive before introducing bills relating to government policies).

71. Id. Art. 48(11).

72. See Philip Bowring, Hong Kong: The Power of the People, InT'L Herald TriB., July 9, 2003, available at http://www.iht.com/articles/2003/07/09/edbowring_ ed3_0.php (stating that Tien's resignation forced the government to defer legislation).

73. Stephen Lam, Sec'y for Constitutional Affairs, Constitutional Affairs Bureau of the HKSAR Gov't, Constitutional Development: Dialogue and Consensus, Address to the Hong Kong Democratic Foundation (July 30, 2004), available at http://www.hkdf.org/newsarticles.asp?show=newsarticles\&newsarticle $=152$.

74. The Honourable Mrs. Rita Fan, President of the Legislative Council, The Relationship Between the Executive Authorities and the Legislature, Address to the Hong Kong Democratic Foundation (Oct. 26, 2004), available at http:// www.hkdf.org/newsarticles.asp?show=newsarticles\&newsarticle=155. 
Accountability is the requirement to account for the authority delegated by the legitimate source of authority. Public servants for example, should treat their clients or the public fairly and efficiently, but the civil service is not accountable to the public. They are accountable to the permanent secretary, who is accountable to the Principal Official, who is accountable to the Chief Executive. Who is responsible to whom, and for what, is the central question in any accountability framework.

Here, too, the HK SAR has much work to do. Principal Officials are political appointments responsible to the Chief Executive, but they are not political party appointments as in most other systems. They are individuals, some from the public service, some from business, civil society and the social sector, brought together temporarily to do a critical job. But what is the glue that holds the team together? There is none, because in every other system, the organizing force comes from the party (or parties). Hong Kong is so anti-party that the legislature passed a bill requiring the Chief Executive to forgo any party affiliation. Yet it is party membership and experience that gives ministers the political skills they need to communicate, organize, plan political strategy, advocate, and lead. If the principal officials do not really operate like a political party then this task falls to the permanent public service. But politics runs against the ethic of partisan neutrality that every public service holds dear. In China, the party is dominant and that country is striving to build an autonomous civil service. In Hong Kong, the public service has historically been unusually dominant in public affairs, responsible de facto for managing both sides of the governance coin-the politically neutral administration that is the traditional task of a professional civil service and the political balancing of competing public interests that, in electoral political systems, is the domain of elected officials and their political appointees.

We believe that the professional civil service of Hong Kong cannot permanently continue to be simultaneously responsible-as it has de facto been at least for the last fifty years-both for politically neutral administration and for managing the political discourse and balancing in a society that faces increasingly complex political matters. Neutral administrative capability is a great asset for Hong Kong; its reputation for competent and honest administration makes it an attractive location for business, investment, and commerce. Maintaining competent and politically 
neutral administration-and answering for administrative competence (rather than for political policymaking)-requires a degree of insulation from political matters. But dealing competently and effectively with the political questions of balancing interests and setting priorities among competing demands for public attention-development, immigration, health, education, transportation, equity, justice, liberty, and security-is also crucial for the continuing success of Hong Kong. Hong Kong must, therefore, in our view, begin systematically to separate the administrative challenges from the political challenges and begin building a cadre of politically minded and experienced people with the inclination and the skills to help navigate the waters of political decision making in a free and open society. The most obvious (though perhaps not the only) way to do this would be by beginning to develop some form of party system.

In his policy address of 2005, Donald Tsang announced changes to the Principal Official system of his predecessor, but the overall direction is unclear. $^{75}$ First, the position of Chief Secretary (Tsang's old position under Tung) has been revitalized. ${ }^{76}$ Rather than the Principal officials reporting to the Chief Executive on a daily basis, all secretaries and heads of Bureaus will report to the Chief Secretary or the Financial Secretary. France has a President who develops macro-policies, but a Prime Minister who runs the Executive and deals with the Legislature day-to-day. ${ }^{77}$ Hong Kong now has a Chief Executive who is clearly the "Communicator-inChief," with the Chief Secretary as the focal point for governmentwide coordination. Further, when the Principal Officer Accountability System was announced in 2002, and the fourteen Principal Officers were all appointed to the Executive Council, many observers were quick to make the analogy that the Executive Council was now comparable to the British, or Canadian, Cabinets. $^{78}$ But Tsang also announced that only he and his three

75. Donald Tsang, Chief Executive of HK SAR, Public Urged to Participate in Politics, Address to Legislative Council (Oct. 13, 2005), available at http://www3. news.gov.hk/ISD/ebulletin/en/category/ontherecord/051013/html/051013en1 1002.htm [hereinafter Tsang, Address to LegCo].

76. Id.

77. See 1958 Const. tit. II (defining the constitutional attributions of the president). See also $i d$. art. 8 (stating that " $[\mathrm{t}]$ he President shall appoint the Prime Minister").

78. See Thomas Crampton \& David Ignatius, Political Appointees to Replace 14 Senior Civil Servants: Hong Kong Realigns Government, INT'L HERALD TRIB., June 21, 
senior colleagues would attend all meetings of the Executive Council, with the other Principal Officials only attending to discuss specific items. Eight new members were appointed to the Executive Council, so this body is now composed with a vast majority of part-time appointees. Easy assumptions about the Executive Council evolving into a Cabinet no longer hold. Today, most Principal Officials no longer seem to be Cabinet "Ministers" in the British or Canadian sense of the term (though they may be like the American cabinet which rarely meets as a collective). Yet the government is becoming more political. Tsang also announced that his government would introduce a small number of positions dedicated to political affairs and communication. The Hong Kong public service would now have to accommodate political officers, just as the Canadian public service learned to do in the 1960s. ${ }^{79}$ Tsang said the main duty of the new officers "will be to support the Chief Executive and the Principal Officials in their political work. This will provide a new channel for people with political aspirations to join the Government to realize their ambitions." that the Accountability System in Hong Kong is still in flux.

Answerability requires that an account be tendered to those to whom an account is due. In most political systems, it is the politicians who do the heavy lifting on political communication. Ministers answer questions in parliament, presidents hold regular press conferences, etc. In Hong Kong, much of the communication function is carried out by the public service in terms of responding to media inquiries; civil servants are known to the public in a way that is astonishing to outside observers (in contrast, Franklin Roosevelt said his advisors and officials must have a passion for anonymity!), ${ }^{81}$ and principal officials are often faulted for communication lapses. Hong Kong's Health Minister, Yeoh Eng-kiong, resigned after the SARS crisis of 2003 largely

2002, available at http://www.iht.com/articles/2002/06/21/kong_ed3_.php (stating that the changes represent "a major step away from the British civil service traditions built during Hong Kong's 156 years as a colony”).

79. See generally Gordon Robertson, The Changing Role of the Privy Council Office, 14 CAN. Pub. Admin. 487 (1971).

80. Tsang, Address to LegCo, supra note 75, at Constitutional Development.

81. Roosevelt said he wanted men "with a passion for anonymity" on the occasion of the release of the Report of the President's Committee on Administrative Management, January 12, 1937. See BARTLETT's FAMILIAR QUOTATIONS, 971 (14th ed. 1968). 
because of legislative criticism about his communication efforts. ${ }^{82}$ The vibrant media of Hong Kong is hypercritical of the government (as is the legislature), and communication skills-most importantly, the ability to answer well-have been sorely lacking. But is it fair to blame the public service or principal officials? In other systems it is the politicians who communicate, and they do it well because they have years of practice and it is their main joband those who rise in the political system tend to be those who are differentially good at it.

\section{INTERNATIONAL COMPARISONS}

Hong Kong has only been dealing with issues of democratic accountability for a few years. Other countries have been dealing with them for centuries. Great Britain, the United States, and Canada have all responded to the accountability question in different ways, and these precedents may be useful to Hong Kong.

England's first Parliament was in 1265, but it was not until the fourteenth century that Parliament began to assume its characteristic form, due to the insatiable demands of the English Monarchs for money to finance wars. ${ }^{83}$ The early parliaments had many similarities to LegCo: the King-Chief-Executive chose his ministers from a personal court, they reported only to him, and Parliament's main role was to pass budgets. ${ }^{84}$ In the eighteenth century, the House of Commons even resembled LegCo by having both directly elected and "functional" constituencies. A great many "rotten" boroughs represented very narrow constituencies: the clothing trade dominated certain seats; ridings on the British coast preferred naval officers; and so on. ${ }^{85}$ The largest category of constituencies, 160 seats, was patronage boroughs in which the Monarch had governing influence on who was elected. ${ }^{86}$ Hong

82. Hong Kong Government, Dr. Yeoh Eng-kiong Resigns (July 7, 2004), http://www3.news.gov.hk/ISD/ebulletin/en/category/issues/040707/html/0407 07en05008.htm.

83. See generally Ronald Butt, A History of Parliament: The Middle Ages (1989) (providing a description of early English parliaments). The classic work on the $18^{\text {th }}$ century parliamentary system is L. B. NAmier, The STRUCture OF Politics At the AcCession of George III (1929). See also The British Constitution in the Twentieth CENTury (Vernon Bogdanor ed., 2003) (providing a contemporary perspective on Britain).

84. See generally BuTT, supra note 83.

85. See 1 NAMIER, supra note 83, at 79-82 (discussing the distribution of seats).

86. See id. at 164-82 (providing an extensive analysis of representation and 
Kong's governing structure in 2005 in many ways resembles Britain's in 1750. Starting in 1768, reformers began to agitate for reform in the House of Commons, and the process took sixty-five years until the famous 1832 Reform Act largely eliminated functional constituencies. ${ }^{87}$ In the eighteenth century, too, the Monarch gradually began the practice of forming a Ministry, not based on personal favourites, but based on leading figures in the House of Commons who could manage or control the House. ${ }^{88}$ Parties came to Britain in the eighteenth century with the Tories and Whigs, and the leader of parties like the Whig Sir Robert Walpole began to be recognized as the "Prime Minister." ${ }^{89}$ In forming a Cabinet, eighteenth and nineteenth century Britain began the process of choosing powerful legislators to fill executive posts. $^{90}$ This is an option still open to Hong Kong, depending on the interpretation of Article 79 of the Basic Law.

The American experience with the Electoral College may have lessons for Hong Kong's Election Committee. ${ }^{91}$ The American

patronage during this era).

87. See Ann Lyon, Constitutional History of the United Kingdom 326 (2003) (discussing how reforms brought some improvement, but resulted in an imbalance of representation).

88. See id. at 302 (discussing the "crisis of 1782-83" whereby the choice of ministers were determined, to a degree, by parliamentary support).

89. See id. at 281 (stating that Walpole has retrospectively been recognized as the first British prime minister and also discussing his ability to effectively administer the House of Commons to his will).

90. See Anthony Seldon, The Cabinet System, in The British Constitution in The Twentieth Century, supra note 83, at 129-33 (discussing the changes to the Cabinet system during the 1900s).

91. In 1789, the Electoral College of the United States was composed of electors from states equal to the State's number of Senators and members of the House of Representatives. U.S. CONST., art. II, § 1. There were 69 electors in 1789 and George Washington was elected unanimously. DAvID MCCullough, JOHN ADAMs 394 (2001). Hong Kong's election committee in 1996 had more than four hundred members and C. H. Tung's election was contested. See Hong Kong Legislative Counsel, History of the Legislature, http:/ /www.legco.gov.hk/general/ english/intro/hist_lc.htm (last visited Jan. 25, 2007). In 1792, Washington was again the unanimous choice for president. MCCullough, at 439. The number of electors per state was decided by a formula, but the method of their choosing was left to the states. U.S. ConsT., art. II, $\S 1$. Some states chose electors by popular vote. William C. Kimberling, The Electoral College 5 (1992), available at http://www.fec.gov/pdf/eleccoll.pdf. In other states, the legislators chose. Id. By 1836, all states except South Carolina chose electors by direct statewide vote. Id. The Electoral College operated without controversy in 1789, 1792, and 1796. By 1800 , however, the states began selecting electors depending on party lists and the 1800 election was one of the most bitter in American history. See McCullough, at 536-57. In 1800, a sitting President John Adams of the Federalist Party was 
Founding Fathers began with the same suspicions about parties as many have today in Hong Kong. The Electoral College in 1789 was just that-a small committee of leading citizens-who chose the best man for Presidency, George Washington. ${ }^{92}$ But by 1800, the small number of electors who voted for the President were themselves selected from party lists-that is, parties had begun to organize around the presidential contest. ${ }^{93}$ By the 1820 s, the number of voters eligible to vote for the Electoral College who would in turn vote for the President had been increased to approximate universal suffrage (except for African-Americans and women!) ${ }^{94}$ The evolution of the American-style system may be suggestive for Hong Kong - the Basic Law provision of an election committee could be retained, but the method of choosing that committee can be widened considerably, even to include universal suffrage. It took the United States about twelve years to begin to change the nature of the Electoral College and about a generation to achieve universal suffrage. If Hong Kong moved as quickly, 2012 would be a target date for significant reform: the electoral base for both the election committee and the functional seats in LegCo, for example, could be doubled by that date as an interim step towards the goal of universal suffrage. The potential for useful incremental reforms to the Election Committee has already been demonstrated by the December 2006 elections for members of the Election Committee. Over 200,000 Hong Kong citizens are entitled to vote for members of this committee, and the democratic camp was successful in electing enough members to sign the nomination papers in order for a democrat to run in the March 25, 2007, election for Chief Executive.

The Canadian experience also has relevance for Hong Kong, because Canada, too, was a colony. ${ }^{95}$ In 1791 Britain introduced a

defeated by Thomas Jefferson, a Republican, in an election that finally had to be decided by the House of Representatives. Id. at 556 .

92. See McCullough, supra note 91, at 393-94, 439.

93. Kimberling, supra note 91, at 5-6.

94. See Jacob Katz Cogan, Note, The Look Within: Property, Capacity, and Suffrage in Nineteenth-Century America, 107 YaLE L.J. 473, 477-78 (1997) (discussing the evolution of suffrage in the United States).

95. See generally Janet Ajzenstat, Once and Future Canadian Democracy: An ESSAY IN POLITICAL THOUght (2003) (describing Canada's constitutional history); Robertson, supra note 79 (describing Pierre Trudeau's introduction of the modern Prime Minister's office); Marc LaLonde, The Changing Role of the Prime Minister's Office, 14 CAN. Pub. Admin. 509 (1971). For a description of how the Prime Minister's Office operated, see Thomas S. Axworthy, Of Secretaries to Princes, 
system familiar to anyone from Hong Kong: a Legislative Council, a British-appointed governor, and an Executive Committee filled with the friends of the Governor. As early as 1810, Canadian reformers were agitating to have the Executive Council composed of legislators who commanded a majority of the House (Pierre Bedard, who championed this theory, was thrown into jail for his efforts). ${ }^{96}$ For many years, both in Lower and Upper Canada (today's Quebec and Ontario), there was an alliance between the local business-oriented elite and the British-appointed governor to keep the reformers at bay. In 1837, the patience of the Canadian reformers had finally grown so thin that there were armed revolts (which Britain and the local militia easily quelled). Canada had to wait until the colonial Master was ready. But with the passage of the Reform Bill of 1832, reformers eventually came to power in Britain, and in 1848, the North American colonies were finally granted responsible government. ${ }^{97}$ It had taken about fifty years for British acceptance of responsible government to catch up with Canadian eagerness to have it: The Basic Law, of course, also has fifty years to run.

Much more recently Canada also innovated around the question of civil service through developing ministerial accountability. Canada developed a strong party system but it inherited a Westminister civil service model of nonpartisan neutrality. By the mid 1960s, the two systems were in growing conflict. The civil service was in danger of being overly political with senior ministers like Lester Pearson (who eventually became prime minister) coming from the public service, and the Canadian version of administrative officers veering into partisan roles. In 1968, Prime Minister Pierre Trudeau rationalized the system: a partisan Prime Minister's Office was created to work in tandem with the civil service cabinet secretariat. ${ }^{98}$ This 100 -person-strong

31 Can. Pub. Admin. 247 (1988). For a general description of the Trudeau government, see Towards a Just SOCIETY (Thomas S. Axworthy \& Pierre Trudeau eds., 1990).

96. See Historica Foundation, Parti Canadien, in The Canadian Encyclopedia (James H. Marsh ed., 1988) (describing the incidence of Bedard's arrest), available at http://www.thecanadianencyclopedia.com/index.cfm?PgNm=TCE\& Params=A1ARTA0006120.

97. See Historica Foundation, The Friendship That Brought Responsible Government, in THE CANADIAN ENCYCLOPEDIA, supra note 96, available at http:/ / www. thecanadianencyclopedia.com/index.cfm?PgNm=ArchivedFeatures\&Params=A27 3 .

98. See J. E. Hodgetts, Prime Minister's Office, in The Canadian Encyclopedia, 
office quickly became the political centre of the Liberal government. Each minister also had a personal political stable of "exempt staff." A political bureaucracy funded by taxpayers, but without the job security of the public service, became responsible for functions like political strategy, coalition building, media communication, and so on. ${ }^{99}$ Trudeau's government also funded for every party not only a portion of election expenses, but also the creation of caucus research offices, or political "think tanks" that served as an alternative home for opposition political staff. ${ }^{100}$ Politically minded individuals could now gain experience (and have careers) outside the civil service. The Trudeau government also funded independent nonpartisan think tanks on economics, science, and foreign policy to give the civil service competition in the realm of ideas and policy science. ${ }^{101}$ In short, the Trudeau system demanded a partnership between policy and politics: the cabinet secretariat was policy proficient but politically sensitive, while the Prime Minister's Office was politically proficient but policy aware. With Hong Kong's office of Chief Executive now having a Director who is a political appointment, a permanent Secretary, and an Information Coordinator, plus the innovation of a small number of political appointees, Hong Kong is moving in the direction of the mixed political-civil-service executive system of Canada.

\section{China Evolves}

China must agree to any fundamental changes in the political structure of Hong Kong. But China, too, is debating how best to achieve accountability and respond to demands for change. These two processes inevitably interact. Since Hong Kong began its

supra note 96, available at http://www.thecanadianencyclopedia.com/index.cfm? PgNm=TCE\&Params=A1ARTA0006475.

99. Id.

100. See Charles Caccia, Democratic Deficit? What Democratic Deficit?, Policy OPTIONS, May 2004, at 50 (stating the operation of research services are available for each political party, allowing "backbenchers" access to researchers to assist them on party issues), available at http://www.irpp.org/po/archive/may04/cac cia.pdf.

101. See, e.g., Ian Brodie, The Court Challenges Program, FrASER Forum, Oct. 2002, at 15 (discussing the 1978 launch by the Trudeau Government of the nonpartisan Court Challenges Program), available at http://epe.lacbac.gc.ca/100/201/300/fraser/fraser_forum/pdf/2002/02-

10/TheCourtChallengeProgram-pp15-16.pdf. 
transition from a colony in the 1980s to an emerging democracy in the 1990s and into the twenty-first century, it has experienced three transformations in Chinese leadership. For the aging generation of Deng Xiaoping that had participated in the Long March, Hong Kong was the symbol of one of China's greatest nineteenth-century defeats, the Opium Wars of the 1800s. ${ }^{102}$ Margaret Thatcher may have initially hoped that Deng might allow some form of British administration under Chinese sovereignty to continue after 1997, but that was a pipe dream. As Deng and Ms. Thatcher negotiated in Beijing in 1982, an exasperated Deng told the Iron Lady, according to her recollections, "[1] ook, I could walk in and take the whole lot this afternoon." ${ }^{103}$ Jiang Zemin became General Secretary of the Chinese Communist Party in June of 1989 and throughout his tenure, Jiang had to cope with the aftermath of the party's brutal crushing of dissent in Tiananmen Square. ${ }^{104}$ Jiang continued and even accelerated the economic policies of Deng, but after Tiananmen, the party leadership felt threatened by enemies from within and out. Stability was (and it could be argued, remains) the mantra, and the war of words with Chris Patten in 1995-97 reflected the trauma that the senior Chinese leadership felt at the time, at even a hint of democratic change. Hong Kong's misfortune was to be a liberal oasis naturally seeking to make a logical transition to "one-person, one-vote" at a time when the Chinese authorities were most sensitive about political reform. On the other hand, if political space does eventually open up in China, Hong Kong provides a convenient test tube of reform.

In 2000, President Jiang brought forth a new ideological construct-the Three Represents. ${ }^{105}$ The ultimate doctrine called for the CCP to "always represent the developmental requirement of China's advanced productive forces, represent the developing orientation of China's advanced culture, and represent the fundamental interests of the overwhelming majority of the Chinese

102. See generally Ssu-yu Teng, Chang Hsi and the Making of the Treaty of NANKING 1842, 13 (1944) (describing the Treaty of Nanking, the concluding treaty of the Opium Wars, as being "brought about through British military compulsion").

103. See DimblebY, supra note 6 , at 46.

104. See generally China's Jiang: Ruling in the Wake of Tiananmen, June 2, 1999, CNN.COM, http://www.cnn.com/WORLD/asiapcf/9906/02/tiananmen/jiang.pr ofile/index.html.

105. Gang Lin, Ideology and Political Institutions for a New Era, in CHINA AFTER JIANG 39, 39 (Gang Lin \& Xiaobo Hu eds., 2003). 
people.” ${ }^{106}$ This new ideological slant was a sign of changing times in a global economy-the Party had expanded its base of support to include intellectuals and entrepreneurs who would be key to China's continued growth which, in turn, would be key for social stability within the country. It appeared as though political reform was in the air as Jiang's term came to a close.

In the winter of 2002, the Chinese Communist party appointed a new General Secretary, Hu Jintao, the fourth leadership cadre since the 1949 revolution, joining Mao Zedong, Deng Xiaoping, and Jiang Zemin. ${ }^{107}$ President $\mathrm{Hu}$ and his Premier, Wen Jiabao lead a technocratic elite, educated in the 1960s and, in the early days of Hu's administration, there were grounds for cautious optimism that this leadership might be open to some political change, unlike the Long March gerontocracy, or those who reacted with such overwhelming force against the Tiananmen protesters. The actions and reactions of China's new rulers have, to date, been mixed. On one hand, the new leadership has made serious attempts to make the state-sector public service autonomous from the party and $\mathrm{Hu}$ has demanded greater accountability within the Party. On the other, the first years of the Fourth Generation have seen a crackdown on the media, a withdrawal of various civil liberties, and an end to the test 'project' in Shenzhen that would have curtailed Party control over that region's day-to-day governance.

In March 2006, when the National People's Congress met, how to respond to rural unrest was the unspoken priority of the Party. According to Tim Johnson, China had 87,000 protests in 2005, more than two hundred per day. ${ }^{108}$ Most occurred in the countryside, where average incomes are less than one-third of urban dwellers. ${ }^{109}$ Repression against such demonstrations has often been severe. In Guangdong Province, for example, in December 2005, villagers in Dongzhou said that as many as thirty people died when police fired upon peasants protesting against the seizure of land for a power plant. ${ }^{110}$ Land is often at the centre of disputes. Families hold bits of land on a long-term lease, but

106. Id.

107. See Lowell Dittmer, Chinese Leadership Succession to the Fourth Generation, in China After Jiang 11, 23-24 (Gang Lin \& Xiaobo Hu eds., 2003).

108. Tim Johnson, Chinese Premier Defends Nation's Internet Policy, KNIGHT RIDDER NEWSPAPER (March 14, 2006).

109. Id.

110. See generally Philip P. Pan, China Wavers on Police Shooting, WASH. POST, Dec. 14, 2005, at A21. 
officials often sell portions to developers without consulting those who are farming. China's village democracy is much touted, but with the recent unrest, some provincial governments are no longer allowing non-Party members to participate in village elections. Premier Wen Jiabao and the new leadership were certainly seized by the issue of the rural divide; in the opening of the 2006 session of the National People's Congress, Wen said, "Building a new 'socialist countryside' is a major historic task." "111 In China's new five-year plan, Wen announced that more money would be allocated for education and health care for the rural poor.

Dealing with official corruption will be a key component to any reform undertaken by the Fourth Generation, as it seeks to ensure future stability and continued support for the CCP. Public opinion polls consistently reveal corruption to be the number one concern of respondents, ${ }^{112}$ and the overall economic losses resulting from corruption have been estimated to be as high as 14.5 percent of GDP from 1999 to the end of 2001. ${ }^{113}$ Public discontent due to corruption has even resulted in limited civic action; peasants in some rural areas have stormed government buildings to demand lower taxes and accuse officials of corruption.

Premier Wen Jiabao also pledged his support for greater official accountability and has vowed to help build a reasonable accountability system. But any change is likely to accord with past practice: criticism or censure will be permissible on somewhat of an ad hoc basis, at the level of the individual and not that of the Party. As such, the larger Party and its leadership remain unaccountable (to all but a few of their equally unaccountable peers), the national legislature lacks autonomous authority and the rule of law remains a distant dream, and some public officials may be held to account for their actions. Communist ideology posits that the CCP embodies the will of the people, and constructs such as checks and balances or the different roles of party, legislature, and government are alien to the Communist theory that the party alone represents the people. So the Beijing leadership is serious about party reform,

111. China Vows More Money for Poor, CNN.com, March 5, 2006, http://www. cnn.com/2006/WORLD/asiapcf/03/05/china.parliament/index.html.

112. See Sunshine Policy to Fight Corruption in China's Capital, PeOPle's DaILY OnLINE (China), Mar. 13, 2002, http://english.people.com.cn/200203/13/ eng20020313_92021.shtml (noting corruption was the top concern of the general public according to surveys by the Chinese Academy of Social Sciences).

113. Hu Angang, Public Exposure of Economic Losses Resulting from Corruption, 4 CHINA \& WORLD ECON. 44, 49 (2002). 
if not democratic reform.

Following much criticism regarding the spread of SARS in 2003, for example, both the minister of health and the mayor of Beijing were sacked. ${ }^{114}$ The President of the National Petroleum Company (NPC) was likewise held to account in 2003, for a gas well blast that killed 243. ${ }^{115}$ The NPC Standing Committee has, in that regard, begun review of a draft law for Civil Servants which would require individuals in leading positions to quit the leadership and take the blame, if their faults or mistakes lead to major loss or social ills.

Institutional reform has also evolved over the past decade, on an extremely limited and sporadic basis, in an attempt to secure social stability and curb public discontent. For example, a referendum in 2003 asked residents in Jiangsu to name the worst performing officials in certain administrative spheres. ${ }^{116}$ The results led to nine local cadres being reprimanded and forced to forgo pay and undertake training. ${ }^{117}$ Some counties in Guangdong province have even begun to open their budgets and hiring practices to limited public scrutiny. ${ }^{118}$ In its Report for 2004, Freedom House further reported that the Chinese people are increasingly able to bring suits against local governments, occasionally winning damage awards. ${ }^{119}$ Legal-aid programs to assist citizens in this regard were first introduced in 1999, and have since grown to close to two hundred government and private agencies. $^{120}$ Such instances and institutions of accountability in

114. Bates Gill, Contagious Confusion: China Will Pay Dearly for the SARS Debacle, INT'L Herald TriB., Apr. 22, 2003, available at http://www.iht.com/articles/2003/ 04/22/edgill_ed3_.php.

115. See Chris Yeung, Accountability System Is Not an Attempt to Increase My Power or to Bring in Yes-men, Chief Executive Tells Legco, S. China Morning Post, April 18, 2002 , at 1 .

116. See Richard Baum, Professor of Political Science \& Director of Center for Chinese Studies, UCLA Int'l Inst., Testimony before the U.S.-China Economic and Security Review Commission (April 14, 2005), available at http://www. international.ucla.edu/article.asp?parentid=23145 (providing testimony to the Congressional Commission on China's state control mechanisms and methods).

117. Id.

118. Id.

119. See Freedom House, Country Report, China (2004), http://www.freedom house. org $/$ template.cfm? page $=22 \&$ cyear $=2004 \&$ country $=2910$.

120. See Embassy of the People's Republic of China in the United States of America, China Strives to Provide More Legal Aid to Ordinary Chinese (Sept. 30, 2004), http://www.china-embassy.org/eng/gyzg/t163026.htm (providing official statistics on the scope of China's legal-aid system). 
irrespective of motivation, the overarching goal of social stability and order has resulted in some preliminary movement toward a more accountable system of governance in China.

Elections at the village level, for example, have been allowed in recent years. ${ }^{121}$ Candidates are chosen from within the Party and choice is often constrained-in some instances severely, due to high levels of coercion and rigged voting. However limited, these elections do provide citizens with some sense of choice and exposure to a form of democratic process.

Faced with widespread rural unrest, events in Hong Kong may not be at the top of Politburo's agenda, but Chinese leadership is aware that Hong Kong could have a "neighborhood" impact on volatile Guangdong. In September of 2004, President $\mathrm{Hu}$ opinioned publicly that democracy is a "blind alley" and, in the winter and spring of 2004, Beijing fired what Christine Loh has called the "Patriot Missives," attacking the democratic movement in Hong Kong, and short-circuiting the electoral reform process for LegCo and the Chief Executive. ${ }^{122}$ But the senior Chinese leadership also agreed to the resignation of C. H. Tung when his weak performance led to hundreds of thousands of Hong Kong citizens demonstrating. ${ }^{123}$ Still, Beijing is certainly unimpressed with the democratic reformers in LegCo. After the failure of Tsang's Constitutional package, mainland legal scholars held a seminar on Hong Kong's Basic Law in April 2006, which was given widespread publicity. Such high-profile events are often a surrogate for the views of the Beijing leadership. One professor said that "Hong Kong's Democratic Party was misleading Hong Kong people through 'blind worship of universal suffrage." "124 The

121. See Embassy of the People's Republic of China in the United States of America, 470 Million Chinese Villagers Vote in Village Elections Last Year (May 18, 2006), http://www.china-embassy.org/eng/xw/t253295.htm (citing an annual report by the Ministry of Civil Affairs hailing the village elections as a "bright point' of the country's efforts to build a democratic polity").

122. See Patrick L. Smith, Hong Kong Stalls on Road to Democracy, InT'L Herald TRIB., Apr. 25, 2006, available at http:/ /www.iht.com/articles/2006/04/24/news/ hong.php (quoting Christine Loh, who said that most democrats "now look to 2012, when legislative elections are scheduled, for the next opportunity to push through substantial changes").

123. Compare Press Release, Constitutional Affairs Bureau, supra note 29 (stating health concerns as the reason for Tung's resignation), with Christine Loh, Tung's Rumours, supra note 30 (challenging the official line of resignation).

124. Beijing Launches Another Attack Against Hong Kong Democracy, Asia News, Apr. 28, 2006, http:/ /www.asianews.it/view_p.php?l=en\&art=6032. 
professor highlighted six shortcomings that must be addressed before China could allow universal suffrage, including more patriotic education for citizens and passing national security legislation. ${ }^{125}$ Since the last effort to pass a package of national security laws brought a half-million people to the streets to march against the Tung administration-and, many think, signaled the beginning of the end of his hold on his office-this would seem to establish a fairly high hurdle to surmount before further progress on democratization could take place.

While Hong Kong shares the Mainland's valuation of social stability, its citizens do not appear to share the Chinese patience for reform. Surveys in Hong Kong consistently show majority support for direct elections, and in the 2004 LegCo elections democratic reformers received 61 percent of the vote. ${ }^{126}$ Such findings are affirmed by a spate of civic activism and mass political protest in recent years. A lack of truly accountable governance and an incomplete system of governing institutions have resulted in: political instability on the streets; rising criticism; increasing levels of ineffectiveness within the government; and unpredictability everywhere. The desire for democratic reform in the Special Administrative Region is peaking as the pace of reform is slowing down and China seeks a more active role in overseeing the Hong Kong Government's management of political developments. It is an unsustainable combination that, if allowed to evolve on the current trajectory, will likely compromise stability.

China, then, is the brooding presence overseeing Hong Kong's political development. Calls by Hong Kong reformers for referendums on democracy may worry the Chinese leadership, but they also demonstrate that there is a real desire for change. ${ }^{127}$ The

125. Id.

126. See 2004 Election Results, supra note 40.

127. Civic Exchange, an independent think tank headed by former LegCo member Christine Loh, has commissioned a report regarding electoral structures and public opinion contexts concerning the 2004 Hong Kong Elections. See Hong Kong Transition Project, Half Way to Where?: The Electoral Structures and Public Opinion Contexts: 2004 Hong Kong Legislative Council Election (2004), available at http://www.hkbu.edu.hk/ hktp/halfway/halfway.pdf. Surveys from January 2004 show that 73 percent of the sample were dissatisfied with the performance of the Hong Kong government and 53 percent were dissatisfied with the relations between Hong Kong and the People's Republic. Id. See generally Christine Loh \& Richard Cullen, Politics Without Democracy: A Study of the New Principal Officials Accountability System in Hong Kong, 4 SAN Diego INT'L L. J. 127 (2003) (describing succinctly the background to Tung's introduction of this fundamental change). 
leadership of the Special Administrative Region may be able to use the local pressures to push Beijing farther and faster than the Communist Party might otherwise like to go. The key to moving forward in Hong Kong is to have a practical program that is fast enough to show democrats that reform is on its way, but is incremental enough so that Beijing's worries about stability are not stoked to a feverous pitch. Stability will only be found in this increasingly unsustainable political environment if a reasonable schedule for reform is clearly set out.

\section{CONCLUSION}

International comparisons have a variety of lessons for Hong Kong, but the main one should be optimism. Many other societies faced similar issues, and Hong Kong's progress so far has been quicker than most. A logical starting point is to aim toward a fully considered democratic accountability system, pick a date that seems reasonable (say, 2012), and work incrementally from now to then to build a system that is coherent and interconnected. Eventually, as in Canada during the colonial era, there will be a change of attitude in the sovereign government, and when that occurs there should be a well thought-out plan ready to go. Meanwhile, steps can be taken to advance the agenda without unduly threatening those in Beijing who are concerned about the implications of democratic reforms in Hong Kong. Donald Tsang has already begun such a campaign, but his first months show that on democratic reform, he is between a rock and a hard place.

Tsang begins his term as Chief Executive with many advantages denied his predecessor. $\mathrm{He}$ is experienced in government, and has natural communications flair. The economy of Hong Kong is on the upswing. According to a recent survey, three-quarters of Hong Kong citizens are now "satisfied," compared with only 16 percent in 2003, the nadir of Tung's regime. ${ }^{128}$ Nearly 70 percent of those polled want Tsang to run again in the next

Loh's Civic Exchange think tank, along with the Hong Kong Policy Research Institute and Synergy Net co-organized a conference on constitutional development in Hong Kong on November 6, 2004, which addressed many of the issues raised in our paper. The results are summarized at http://www.hkpri. org.hk/passagesPDF/Others/ConferenceReportNov04_English.pdf.

128. Hong Kong Transition Project, National Democratic Institute, Parties, Policies and Political Reform in Hong Kong (2006), at 3, available at http://ndi.org/ ndi/library/2007_hk_transition_050106.txt. 
Chief Executive election in 2007. ${ }^{129}$

But even with a dynamic new Chief Executive and a return of economic growth, the fault lines of Hong Kong's political system prevent progress. Recently, the Hong Kong Transition Project reviewed the first months of the new government and concluded "Tsang cannot deliver strong governance without the parties; but neither can the parties deliver solutions to people's problems without the government . . . the system remains fundamentally flawed." ${ }^{130}$

Tsang must persuade Beijing to move farther, faster. Beijing has ruled out universal suffrage for the 2007 and 2008 elections, so the goal must be to concentrate on the election of 2012. But Tsang must also engage with Hong Kong's political parties, and here the task may be just as difficult as dealing with Beijing.

Parties do many things in a democratic system: they decide which problems become "public" and which remain private; they articulate concerns and values; they develop policy proposals and platforms to deal with the concerns they have championed; they persuade blocs of voters that their agenda is the right one, and organize those blocs to support their candidates in elections. But in Hong Kong, the parties do few of these things. The March 2006 Hong Kong Transition Project Survey shows that the public does not readily identify the parties as standing for distinct policy positions, except in the broadest possible strokes of the Democratic Party championing human rights, and the DAB being in favour of closer relations with Beijing. Beyond this, everything else is unclear. Without distinct social and economic platforms, the parties gain their identity largely by being opposed to the Executive on an ad hoc basis. Yet the Executive needs the parties to pass measures in LegCo. Hong Kong's political fault lines are structural, not personal.

To achieve a better relationship between the Executive Committee and the Legislative Committee, some Principal Officials should be drawn from the legislature and the existing parties. For example, party leaders from the Liberal Party have sat on the Executive Council, but they have never administered a department. As it stands, the government has no party to defend it or to organize the business of LegCo-why not appoint LegCo members

129. Id.

130. Id. 
of the Executive Council as principal officials and give them executive authority? Parties will act responsibly only if they are given real responsibilities. Hong Kong is a system of government with a weak base of support in the legislature. Britain's precedent of having Ministers come from the legislature should be tried. Some argue that Article 79(4) of the Basic Law, stating that a member of LegCo must resign "when he or she accepts a government appointment and becomes a public servant," precludes a LegCo member becoming a principal official. But this depends on how one defines "public servant." Principal officials in Hong Kong are Ministers; and in other systems, Ministers are not considered civil or public servants. They are politicians. An interpretation of the Basic Law allowed the creation of the Principal Official Accountability system without amending the Basic Law, and a similar broad interpretation of the Basic Law could conceivably allow Principal Officials to be drawn from LegCo. Certainly there is now a precedent of inviting LegCo members to join the Executive Council.

Even if Article 79 cannot be interpreted to allow LegCo members to become ministers, there is another route to achieve party engagement with government. The Chief Executive could strike a bargain with willing parties that they will have the right to nominate principal officials in exchange for party support for the administration in LegCo. Under such a system, parties would begin to develop distinctive platforms in health or the environment which would form the core of their appeal to voters, and if they were successful, this would give such a platform democratic legitimacy. To implement their ideas, the parties would nominate a minister (subject of course to the approval of the Chief Executive). The Chief Executive in turn would bargain and build a coalition of support through such parties, both in LegCo and with the public at large. The Executive Council, which is a part-time body, still has great power under the Basic Law to be consulted on all important policy issues. The Executive Council now includes some leaders of LegCo parties in a non-executive capacity, and these leaders would be joined by their nominees as principal officials who would also be members of the council. Under such a system, parties would gain a share of government, and the Chief Executive would gain a guaranteed base of support in LegCo. Such a mechanism would not be a law, but it could become a convention, and in democratic societies like Britain or Canada, 
much of their constitutions are convention, not statute.

Hong Kong must develop a competitive party system. Parties are the essential ingredient that makes the British, American, and Canadian systems operate. It is the party glue that connects the pieces. Hong Kong already assists parties with election expenses: like Canada, there could also be grants to create party think tanks or research bureaus that do political thinking. Independent nonpartisan think tanks could also be seeded with government money to provide policy competition to the civil service and educate the wider public. The restriction on party membership for the Chief Executive should be dropped. Hong Kong should invest in party development just as it does in skills development. The Democratic Party, for example, only has 631 members (July 2006 figures) out of a voting population of 3.2 million. ${ }^{131}$ Parties need to become Hong Kong's vehicle for change and political engagement. Weak parties are the weakest link in Hong Kong's emerging system of democracy.

District Councils, first established in 1982, are the most democratically elected institutions in Hong Kong. Out of a total of 529 members, four hundred are elected by universal suffrage, with 102 members appointed by the Chief Executive. The function of District Councils, however, is purely advisory and is limited to local issues such as libraries. But another lesson from history is that town hall meetings, local school boards, and municipal governments generally are the seed stock of democratic governance. Through such neighborhood institutions, citizens are connected to government, and by participating in local government elections, prospective politicians learn the subtle arts of democracy. Many members of the Congress in the United States, or members of Parliament in Canada have started their careers by running for the local school board or as an alderman. Donald Tsang recognized the importance of District Councils by proposing in his 2005 package of reforms that, of the ten new seats proposed for an expanded LegCo, the five functional seats would come from the District Councils, in addition to the one functional seat now assigned to that sector. $^{132}$ In essence, Tsang proposed a ten-seat

131. See Hong Kong Democratic Party Website, http://www.dphk.org/e_site/ index_e.htm (last visited Jan. 25, 2007).

132. See Sylvia Hui, Hong Kong Proposes Political Reforms, Assoc. Press, October 19, 2005, available at http:/ / www.sfgate.com/cgi-bin/article.cgi?f=/n/a/2005/10/ 19/international/i184320D72.DTL. 
addition to the democratic base of LegCo (five new geographic seats elected by universal suffrage and five new functional seats from District Councils). Further, the reform package proposed the expansion of the election committee from eight hundred to 1,600, with all 529 members of District Councils added to the committee making them the largest single group. ${ }^{133}$ The democratic credibility of District Councils would be even more enhanced if the Chief Executive gave up the power of appointment (why appoint members if the function is only advisory?). Most importantly, if the work of the District Councils could also expand to areas more significant to citizens, such as local planning decisions, the significance of this entry level position into politics would greatly expand. District Councils could become the first rung of the ladder to an emerging political class.

Hong Kong has already demonstrated "people power," with hundreds of thousands marching in the streets. The resignation of Chief Executive C. H. Tung in 2005 further demonstrated the power of public opinion. Donald Tsang's first actions show that he realizes that the existing government structure must evolve to adapt to today's new reality of an engaged citizenry. Hong Kong is no longer only a model of laissez-faire economic development. It is now a test case for peaceful political transition. On the issue of Hong Kong's democracy, the whole world is watching.

133. Id. 